\title{
Skeletons in the Closets: Gay Themes in Philippine Fictions in English
}

\author{
Christopher Yap Wright \\ National University, Philippines. ORCID: 00oo-0002-2230-0798. \\ Email: christopher.yap.wright@gmail.com
}

Received May 11, 2017; Revised July 2, 2017; Accepted July 10, 2017; Published August 17, 2017

\begin{abstract}
The study aimed to ascertain the portrayal of gay identity in the selected Philippine Anglophone fictions titled "The Chamber of the Sea," "The Doll," and "The Husband" through exploring their literary themes. Most importantly, it sought to determine the texts' presentations of gay-self through Imaging with Fassinger and McCarn's Model of Gay Individual Identity Development. Further, the predominant themes of denial of the self, eroticism towards others, and tragedy of discriminations were identified and explored as the study examined the Filipino gay protagonists' significant experiences. The study revealed that the literary gay-self imaging affirmed the homosexual representations in the Philippine Anglophone fictions. Such representations were both seen in ghostly and implicit manners through the gay male characters namely, Tio Teban from "The Chamber of the Sea," Elpidio from "The Husband," and Narciso a.k.a Boy/ Sising from "The Doll." Also, the central characters' setbacks and unfinished self-issues-the skeletons in their closets, including their struggles with being different as to their physical, emotional, and sexual interests toward their co-species were shown. Despite the differences of the authors, the Filipino gays through their experiences had common familial and societal struggles to survive. This study has clear implications for the understanding of the Filipino gay literary characters in fictions.
\end{abstract}

Keywords: Filipino Gays, Queer Literature, Gay-Self Imaging, Gay Themes.

\section{Introduction}

Across nations, gay men have always been creative, interesting, and talented. But despite their accomplishments, societal norm antagonizes their queerness. The social stigma neither chooses, nor limits the victims as some of the world's well-known writers have experienced the difficulties of living as repressed Queers such as Ralph Waldo Emerson, Walt Whitman, Oscar Wilde, W.H. Auden, Samuel Butler, Roland Barthes, and much more. ("Famous Gay Men," 2015)

With the fear of social banishment, a culture of silence about gays' real identities has been refined. The phenomena of hiding and living with skeletons in the closets do not only happen in real-life but also in literature as revealed by the narratives of the Filipino authors. Fortunately, such silence does not remain inaudible in the Philippines particularly when the emergence of gay liberation theory in the country happens. This rise has led to the development of queer writings that highlight gays' experiences, which have been narratively chronicled by many of the most significant Filipino English-language writers.

(c) AesthetixMS 2016. This Open Access article is published under a Creative Commons Attribution Non-Commercial 4.0 International License (http://creativecommons.org/licenses/by-nc/4.0/), which permits non-commercial re-use, distribution, and reproduction in any medium, provided the original work is properly cited. For citation use the DOI. For commercial re-use, please contact editor@rupkatha.com. 
It is remarkable to note that queer writings are not only exclusive to gay writers but also to women pen-pushers who, in a way or the other, have made contributions in the receptions of queer literature in the Philippines.

In a nutshell, queer literature refers to a lite-nature writing that involves characters, plot lines or themes which portray male homosexual behavior that has been either explicitly shown or implicitly included to some of the texts identified from the pre-colonial to the modern-age Philippines.

The downgraded Bakla, who is the Filipino gay familiar to many, has not been the only homosexual existing in the Philippine letters. In fact, Wright (2017) asserted that the literary Filipino gays' characteristics based on their performances are varying; hence, their traits are not fixed, and they are diverse from each other in so many ways.

As the literary periods in the country proceed, gay identity presentation varies. On the onset, the Philippine contemporary English literature has first depicted the emergence of homosexual themes in literature in the last two decades of the Twentieth century. Garcia (1996) claimed that in the 1980s, many more gay-themed feature articles, interviews, reviews, and news stories came out regularly in the country.

Meaningfully in the 1990s, the increase in gay awareness continued through the following queer publications: Margarita Go-Singco Holmes's “A Different Love: Being Gay in the Philippines" in 1993, and Danton Remoto and J. Neil Garcia's "Ladlad" in 1994. In the same year, monthly gay magazines were published. In 1998, "Tibok", an anthology of lesbian writing came in print. Also, the first LGBT newspaper in the Philippines called Manila Out was published. In 2007, Outrage Magazine was established as the first Web-based publication for the LGBT Filipinos (UNDP, 2014).

The genre specificities change as the country proceeds with time. The homosexualthemed narratives do not remain exclusive to print works but also in the Philippine media. In fact, three of the country's mainstream local television channels aired homosexual-themed programs. To cite, the $\mathrm{TV}_{5}$ had "Positive," a drama that tackled the life of a repressed Queer who was diagnosed with HIV. The GMA7 had televised "Out!" in 2004 which was a magazine TV show that was banned allegedly because of politics; followed by gay-themed drama television series "My Husband's Lover" (2013), and a transsexual-themed drama series "Destiny Rose" in 2015. Remarkably, the ABS-CBN in 2016 aired "Till I Met You" with reception of a gay character.

These programs and publications suggest how gay representations in the Philippine media are progressively developed and shown. The manners of presenting the Filipino sense and understanding of homosexuality both in media and letters are varying.

To date, there have been many studies about the Philippines' fictional imaging of gay self, but only a limited number of which focused on the themes of denial of the self, eroticism towards others, and tragedy of discriminations which this study is based on.

Concentrating only on written works it aims to add base data and fill a gap in the literary field through the selected Philippine literary pieces written by some of the established Filipino writers in English.

Specifically, this study seeks to answer the following questions:

1) How do the selected Philippine fictions in English portray gay identity? And,

2) How do the narratives' predominant themes such as denial of the self, eroticism towards 
others, and tragedy of discriminations explain the Filipino gay experiences?

\section{Literature Review}

The Philippines' queer writing does not only show the subject's problematics, politics, and motives, but it mainly exposes the Filipino gay experiences through gay-self imaging and gay themes.

\subsection{Gay-Self Imaging}

The process of self-presentation of gay identity either through (1) gay-self inhibitions, or (2) flaunting the "fabulous gay self" through a homoerotic way, gender-crossing, or transvestism in literature are both illustrations of literary imaging. The latter can be recognized as rich cultural features of the pre-colonial Philippines. In fact, Garcia (2014) conducts a historical survey during the pre-colonial which states that "local men dressed up in women's apparel were called, among others, bayoguin, bayok, agi-ngin, asog, bido, and binabae" (p1o). These men are well-accepted for they do not only embody cultural significance as they function as "highly respected leaders and figures of authority" (p1o) but also, they exude aesthetic beauty, which Garcia defines as "downright astonishing and threatening." In relation, Zeus Salazar (1989) concept of femininity in the pre-and early colonial Philippines asserts that gays accomplish duties as "intermediaries between the visible and invisible worlds" (p1o). This idea has been reflected by literary works.

While the former merely suggests the self-consciousness and inability act in a relaxed and natural way that in many ways referred to as offshoots of homophobia. In the study of Ross and Rosser (1996) among gay men, they identified four dimensions of homophobia that include: (1) concern about being publicly identified as being gay; and, (2) concern about the stigma associated with being gay outside the gay world.

Complementarily to the aspects, Frable et al. (1997) asserted that the more stigma on gays, the more negatively they perceived themselves. In the Philippines, literary works have showcased some inhibited and repressed experiences of gays. As examples, the anthologies of Ladlad: An anthology of Philippine gay writing, which was first published in 1994, up to its recent version published in 2014 by Danton Remoto and J. Neil Garcia, courageously cover such inhibitions of some of the Filipino gays.

With the presence of gay imaging, it suggests that the existence of the Filipino gays is not contemporarily discovered or newly identified. In fact, they must have been significantly performed cultural roles in the ancient Philippines. Also, literature has been an avenue for gay imaging.

\subsection{Fassinger and McCarn's Model of Gay (Lesbian)Identity Development}

Ruth E. Fassinger developed this design in 1996 as a model of lesbian identity development. In 1998, it was then utilized and validated for men. Further, Susan R. McCarn, a colleague of Fassinger's, studied personality development of thirty-eight lesbians with dissimilarities in age, education, race, ethnicity, and occupation. The results lead to the establishment of two processes (individual and group), and four phases that follow:

1. Awareness: This phase commences with the realization that he/she may have desires or feelings that are "different from the heterosexual norm and therefore from the predicted self” (McCarn \& Fassinger, 1996, p. 522). 
2. Exploration: In this phase, he/she (gay) would have "strong relationships with or feelings about other (gay men) women (lesbians) or another woman in particular...but will not necessarily involve exploration of sexual behaviors" (McCarn \& Fassinger, 1996, p. 522 ).

3. Deepening/Commitment: During this phase men/ women (gays) can identify

themselves as bisexual, heterosexual, or as gays/ lesbians after exploring their sexual identity.

4. Internalization/Synthesis: In this phase, "a woman (or a gay man) experiences fuller self-acceptance of desire/love for co-species as a part of her overall identity" (McCarn \& Fassinger, 1996, p. 523). McCarn and Fassinger (1996) acknowledged that although women/ gay men in this stage may remain "closeted" in different areas of their life, they still "believe it is unlikely that one could reach the final phase of individual sexual identity development without beginning to address the group membership questions in the parallel branch of the model" (p. 523).

\subsubsection{Gay Themes}

Through time, the positive receptions to the Filipino gays drastically change from being Through time, the positive receptions to the Filipino gays drastically change from being welcomed to being disgraced concerning the Pre-Hispanic period to the contemporary time of the Philippines. Opportunely, the humiliation lessens by the development of queer writings that highlight gays' experiences as they struggle for acceptance.

The gay-themed writings have been developed as the Philippine publication in English flourishes with the appearance of new printings: Bulletin Today, The Inquirer, Malaya and the People's Journal. Although individual gay poems and literary stories appeared in various publications during the 1980s, it was not until the 1990s that books on gay themes began to be published widely. The publications of Philippine-centric gay writings happened after the writers Danton Remoto, Neil Garcia, Ronald Baytan, and others courageously come out from their literary closets, and this led to the publications of other homosexual-themed works.

Moreover, Remoto and Garcia (2010; 2014) presented a collection of different genres that discussed the flight, adversities, personalities, and emotions of homosexual characters. The anthology connotes an urgency of forming a community that significantly welcomes all kinds of homosexuals. With the same call, Garcia (2012) gathered various gay-themed narratives by the Philippines' best fictionists in English like Jose Garcia Villa, Nick Joaquin, Edith L. Tiempo, Ophelia Alcantara-Dimalanta, Gilda Cordero Fernando, R. Zamora Linmark, Ninotchka Rosca and Bino A. Realuyo.

The gay-themed authors, amid challenges, are boasting the ingenuity and intelligence of the major gay characters as they struggle to survive. The gay imaging of the Filipino gay self (identity) across genres differ. Despite genre variations, gay literature has all aimed never to mistreat the plight and unfortunate events that mirror the Filipino homosexuals' real-life experiences that ask for a better understanding of the homosexual experiences.

\section{Methodology}

Grounded in the objectives of ascertaining the process of gay-self imaging, and explaining the Filipino gay experiences through predominant themes, this textual analysis of the selected 
Philippine English Fictions was conducted. The method involved, thematic analysis, and set criteria established by the author to ascertain gay-self imaging. Further, the corpus in this study referred to selected fictions by the Filipino authors.

\section{Procedure}

The researcher significantly conducted the following steps. First, the researcher- identified the criteria for ascertaining gay identity mirrored by gay-self imaging. Such criteria were patterned to Fassinger and McCarn Model of Gay and Lesbian Individual Identity Development, which centered on the character's awareness, exploration, deepening/commitment, and internalization or synthesis. Subsequently, the parameters for descriptive-critical analysis were objectively conducted through the following procedures: (1) The researcher used the Thematic analysis to explain gay experiences in the narratives; (2) The study was guided by the researcher-identified themes that included, denial of the self, eroticism towards others, and tragedy of discriminations. Finally, the researcher engaged in rigorous literary thematic analysis.

\section{Results and Discussion}

This study aimed to ascertain the portrayal of the Philippines' fictional imaging of gay self and to explain the gay experience through the themes of denial of the self, eroticism towards others, and tragedy of discriminations.

\subsection{The Portrayal of The Filipino Gay-Self through Imaging}

As the authors namely, Edith Tiempo (The Chamber of the Sea), Emigdio Alvarez-Enriquez (The Doll), and Jaime An Lim (The Husband), unfolded their narratives - which were all, as the researcher would claim, well-written - they did not just affirm gay identity of the protagonists who had intrinsically felt being different in their physical, emotional, and merely sexual interest toward their co-species, but also mirrored setbacks and unfinished self-issues - their skeletons in their closets.

The gay-self imaging, a process of showing one's queerness, is not exclusive in displaying how the Filipino gay protagonists physically performed their ideas and personalities.

The process of gay-self imaging is transcending beyond the physical and actual performances. The possibility of the thought-imaging process as an aspect to consider is highly possible for they represent the "parts" of the individual's being, either be the conscious, or the subconscious. Affirming to this are the narratives used in this study, whose protagonists' concepts of identity could be subjected to critical analyses, for they did not just succeed to adhere to what they supposed to be performing, but also, they conceived ideas beyond their 'norms.' Such acts, the core of thoughts-imaging, as what the researcher would assert, were all significant data insofar with the discussion of "imaging."

Many Filipino gay protagonists were either be the repressed-versions of themselves or the "newly" liberated individuals. To cite, Tio Teban, Elpidio, and Narciso had sexually-repressed gay experiences from which unspeakable libidinal desires could not hold by their closets. As a matter of fact, despite strong regulation of sexual desires, all protagonists were proven "guilty," regardless of the manner, of showing their homosexuality.

The literary gay-self imaging affirms the homosexual representations in the Philippine Anglophone fictions. Such representations were both seen in ghostly and implicit manners which were identified through a set of criteria patterned to Fassinger and McCarn (1997) Gay Individual 
Identity Development Model, which looks at identity development from a personal perspective. The gay identity portrayed by the gay male characters namely, Tio Teban from "The Chamber of the Sea," Elpidio from “The Husband," and Narciso a.k.a Boy/ Sising from “The Doll," suggested that gays could be remarkably mysterious, sometimes ashamed or embarrassed by their feelings without apparent reasons. Fassinger and McCarn (1997) concept of self-awareness of being different was identified precisely when the characters knew it; however, the awareness they had might not exclusively come from themselves but could be triggered by other people around. To cite, when Narciso was fascinated with his mother's doll, he was satisfied with secretly playing with it. He even identified himself with it. In fact, Narciso felt broken when his father forcefully threw the doll. This was affirmed by the descriptions from the text:

The blood crept up his face and pinched his ears. He couldn't speak, he couldn't move. He could only stare (at the doll--himself) until his mother taking him in her arms cradled his head between her breasts (p.472).

Also, Tio Teban's fondness at doing domestic chores, and be at the "world of fragile things" set his awareness of effeminacy, which was also exhibited through his cleanliness and meticulous nature. With a different case, Elpidio's self-awareness was at ease in which some men armed themselves with nothing deadlier than a quick hand or a glib tongue, which enabled them to jump from one torrid affair to another; and he even, "does not know how to chase skirts (p.1). Such inadequacies make him surprised at his self, especially when he found that Ellen was an interesting person. "He was surprised at his susceptibility in realizing that he was excited by her." (p.2) But this excitement was dissimilar from the source of excitement that other men feel.

Except for Narciso, the individual exploration depictions happened when Elpidio and Tio Teban had their explorations of strong, erotic feelings toward people of the same sex namely, Tommy Kabuyao, Elpidio's closest and most intimate friend, and the unnamed naked diver to whom Tio Teban was attracted.

The deepening or commitment stage happened when the gay protagonists had come to the point of committing to self-fulfillments, and crystallizations of their choices about their sexuality. The original synthesis of pushing their desire or love had developed their overall identities.

\subsection{The Explanation of the Filipino Gay Experiences through Literary Themes}

The Filipino gay experiences were explored through the predominant themes such as denial of the self, eroticism towards others, and tragedy of discriminations, despite the differences of the authors.

\subsubsection{Denial of the Self}

Surprisingly, as the researcher identified the portrayal of the Filipino gay-self through imaging, the theme of "denial of the self" was affirmed by gay protagonists namely, Tio Teban, Elpidio, and Narciso. The actions of the three had portrayed something beyond what was perceivable and palpable. Suggestive as they seemed, the depicted Filipino gay-self had always been hiding because of familial, social, and moral issues that consistently pressured them.

Concerning hiding, the denial of the self was predominantly practiced by Elpidio when he married Ellen while he had an intimate feeling to his best friend, Tommy. One discreet identification of Elpidio's denial was his mysterious act of fading into the shadow in the corner especially when: "addressed directly, he answers with a few words or just smiles and even becomes indifferent with others (p.3)." Elpidio's intimate affair with Tommy, after whom he 
named his son, came to ostensibly an end when he decided to establish a family. Unfortunately, his true self, no matter how he denied, had manifested more unacceptable, that was, kissing his child on the mouth.

Complementarily to the situation of Elpidio, Narciso struggled to be at peace, so he denied his "real self." Repressed that he is, Narciso has eaten his masculine culture so as not to live a difficult life. There had been no way out but denied his self; otherwise, the pathetic fate of his doll might also be his own. When Narciso met and slept with a bar girl, it was viewed as a chance to prove that he is a "real man" notwithstanding his father's; the girl's and society's doubts about his masculinity. Sad to say, self-denial was difficult to embrace, so Narciso killed the girl with harsh details of death that were described below:

[The woman] stretched herself awake, and slowly a long clammy coil like the sinuous body of the serpent ... His flesh crawled. With a quick movement, he caught the coil in a strong grip, twisting it. (p.476)

The case of Tio Teban's denial has been depicted as he furiously washes his underwear whenever he gets angered by something or someone. He turns his ire to his underwear and feverishly washes it. The effect of this behavior is explained by the story itself:

It seemed as though the sight of his intimate wear blowing fresh and white on the clothesline in the yard washed his soul clean of resentment, too (p.662).

Tio Teban equates the dirt to his intimate apparel with his self-flaws. Whenever he sees his personal things hanging free of dirt in the clothesline, he gets the feeling that he is clean, too, free of the turmoil he has gone through.

As affirmed by the gay characters, Tio Teban, Elpidio, and Narciso, self-denial has always been a process to conceal and repress one's gay-self or being "closeted".

This action is seen acceptable to the society for it concealed factors and ideas that would violate the social norms. However, gay's secrecy and denial lead to feelings of shame and embarrassments that will give rise to a more unacceptable action.

\subsubsection{Eroticism towards Others}

The protagonists' gay-self was identified no matter how the characters hid them. The researcher also considered the characters' minds, specifically on how they think about sexual desires towards others.

The protagonists, Tio Teban, Elpidio, and Narciso, have different sexual and romantic engagements. Among the three, Narciso seems to be the most "interesting" as he challenges the symbolic sexual urges caused by the pleasure provided by the woman. By this, the researcher claims, that the Narciso's character portrayed what is beyond the tangible and noticeable-- the darkest and corrupted aspect of his mind.

To have the sense of "acceptance" by both his society and his ego, Narciso tries to follow the norms as he sexually interacts with a girl at the bar. He bases his actions on the parameters of what and how to be a "man". However, after the intimate encounter, he kills the woman who teases and doubts his manliness.

Were it not for the murder committed by Narciso in the "The Doll”, Elpidio Flores would have been the worst character. His unbridled desire for his lover has pushed him to project this deviant behavior toward his son. His repressed eroticism surfaces as he thinks of Tommy. 
Thinking of his lover, he kisses his child on the mouth twice. The story ends with Elpidio sobbing into his handkerchief. This powerfully shows how remorseful he is- all for kissing his child, marrying Ellen, and deserting Tommy.

Lastly, Tio Teban, among all, was the only gay character who had no sexual-physical involvement. However, he was smitten by the naked diver he always sees at the sea shore. The eroticism, at the very least, an attraction, makes him very mindful on the very detail of the man's naked body. Secretive that he is, Tio Teban regards to his musings, writings, and letters to be very private and intimate. This makes him very suspicious of everyone who might "stumble upon" them.

\subsubsection{Tragedy of Discriminations}

Much of the sharp conflict that a gay character had was not just referring to the results of social and physical battles but struggles that were more painful and dangerous than those mentioned above-the conflict within himself.

As gays continued the struggles to be acceptable by their society, they concealed, denied, and repressed themselves. These acts are considered worse results of the tragedy of discriminations as they lead to the worst actions, not only to their society but themselves as well. Because of fear of social and familial prejudices that usually result to expulsion, Tio Teban, Elpidio, and Narciso have acted against themselves.

When Narciso sleeps with a bar girl, then Elpidio marries Ellen, and Tio Teban excels in academic pursuit and finishes Master of Arts in Political Science, each act is rooted in avoiding judgments, including but not limited to verbal and physical discriminations, and emotional pressures.

The fact that the homosexual protagonists under study have been subjected to almost all the foulest experiences in life like being verbally discriminated against by society, or worst not being accepted by their family, is the main reason why they have denied themselves to save from the pain of rejection caused by other people.

\section{Conclusion}

The present study aimed to ascertain the portrayal of gay identity in the selected Anglophone fictions titled, "The Chamber of the Sea," "The Doll," and "The Husband" penned by the Filipino writers namely, Edith Tiempo, Emigdio Alvarez-Enriquez, and Jaime An Lim.

Further, this study explored the literary themes such as denial of the self, eroticism towards others, and tragedy of discriminations. Most importantly, this paper sought to determine the texts' presentations of gay-self through Imaging with Fassinger and McCarn's Model of Gay Individual Identity Development.

The study revealed the following findings: (1) the literary gay-self imaging affirms the homosexual representations in the Philippine Anglophone fictions. Such representations were both seen in ghostly and implicit manners which were identified through the set of criteria patterned to Fassinger (1996) Gay Individual Identity Development Model. The gay identity portrayed by the gay male characters namely, Tio Teban from "The Chamber of the Sea," Elpidio from "The Husband," and Narciso a.k.a Boy/ Sising from "The Doll," suggested that they were remarkably mysterious, sometimes ashamed or embarrassed by their feelings without apparent reasons. Also, they had not only intrinsically felt being different in their physical, emotional, and 
merely sexual interest toward their co-species, but also mirrored setbacks and unfinished selfissues - their skeletons in their closets; (2) The Filipino gay experiences were explored through the predominant themes such as, denial of the self, eroticism towards others, and tragedy of discriminations, despite the differences of the authors.

Despite the provided new interesting insights about the Filipino gays, this study remained limited. As regards to the methods, this study employed a textual analysis, which limited the research regarding the data provided by the texts alone. Therefore, caution should be made on the interpretation of the findings provided. Further studies may deal with real key informants through a phenomenological study. Despite its limitations, the present study has clear implications for the understanding of gay literary characters in the Filipino fictions.

\section{References}

Famous Gay Men: List of Gay Men Throughout History. (2015). Retrieved January 24, 2017, from http://www.ranker.com/list/famous-gay-men-list-of-gay-men-throughout-history/famous-gay-andlesbian

Fassinger, R. E. (1998). Lesbian, gay, and bisexual identity and student development theory. In R. L. Sanlo (Ed.). Working with lesbian, gay, bisexual, and transgender college students: A handbook for faculty and administrators (pp.13- 22). Westport, CT: Greenwood Press.

Fassinger, R. E. and McCarn, S. R. (1997). Revisioning sexual minority identity formation: A new model of lesbian identity and its implications for counseling and research. Counseling Psychologist. 24: 508-534

Frable, D.E.S., Wortman, C. and Joseph, J. (1997). Predicting self-esteem, well-being and distress in cohort of gay men: the importance of cultural stigma, personal visibility, community networks, and positive identity, Journal of Personality, 65 (3):599-624.

Garcia, J.N.C. (1996). Philippine Gay Culture: Binabae to Bakla, Silahis to MSM. Quezon City: University of the Philippines Press

Garcia, J.N. C. (2012). Aura: The Gay Theme in Philippine Fiction in English, Anvil Publishing.

Garcia, N. (2014), Post-Colonialism and Filipino Poetics: Essays and Critiques, University of the Philippines Press and Flipside Publishing

Garcia, N. (2014). Postcolonial Perverse Volume 2: Critiques of Contemporary Philippine Culture, Philippines: UP Press

Garcia, J. N., \& Remoto, D. (1994). Ladlad: an anthology of Philippine gay writing. Pasig, Metro Manila, Philippines: Anvil.

Holmes-Singco, M.G. (1993). A Different Love: Being A Gay Man in The Philippines. Pasig, Metro Manila, Philippines: Anvil.

McCarn, S. R. \& Fassinger, R. E. (1996). Revisioning sexual minority identity formation: A new model of lesbian identity and its implications for counseling and research. The Counseling Psychologist, 24(3), 508-534.

Ross, M.W. and Rosser, B.R.S. (1996). Measurements and Correlates of Internalized Homophobia: A factor Analytical Study. Journal of Clinical Psychology, 52 (1):15-21

Salazar, Z. (1989). Ang Babaylan sa Kasaysayan ng Pilipinas. Quezon City: University of the Philippines Women Studies, pp. 35-41. 
UNDP, USAID (2014). Being LGBT in Asia: The Philippines Country Report. Bangkok

Wright, C. Y. (2017). The Queer Queen Quivers: The Gays in Selected Philippine Prose in English. Rupkatha Journal on Interdisciplinary Studies in Humanities, 8(4), 157-168. doi:10.21659/rupkatha.v8n4.18

Christopher Yap Wright teaches literature at the National University, Philippines. Concurrently, he studies Doctor of Philosophy in Philippine Studies major in Philippine Literature in English at the University of the Philippines, Diliman. He holds a Master of Arts in English Language Teaching from the Polytechnic University of the Philippines, Manila, and Bachelor of Arts in Literature/ Bachelor of Secondary Education major in Literature (English Stream) from the Philippine Normal University, Manila. His research interests include Philippine studies, literature, education, and gender studies. Further, he publishes research and conducts seminars and academic talks about the Philippine education and literature teaching. 